\title{
DISCRETIONARY APPEALS OF DISTRICT COURT INTERLOCUTORY ORDERS: A GUIDED TOUR THROUGH SECTION 1292(b) OF THE JUDICIAL CODE
}

By enacting section 1292 (b) of the Judicial Code in $1958,{ }^{1}$ Congress increased the number of appealable district court interlocutory orders. ${ }^{2}$ Appeals may now be granted:

When a district judge, in making in a civil action ${ }^{3}$ an order not otherwise appealable under this section, shall be of the opinion that such order involves a controlling question of law as to which there is substantial ground for difference of opinion and that an immediate appeal from the order may materially advance the ultimate termination of the litigation, he shall so state in writing in such order. The Court of Appeals may thereupon, in its discretion, permit an appeal to be taken from such order, if application is made to it within ten days after the entry of the order: Provided, however, that application for an appeal hereunder shall not stay proceedings in the district court unless the district judge or the Court of Appeals or a judge thereof shall so order.

Since the new procedure has not been extensively used in its first year, its impact on federal practice remains an open question.

Section 1292(b) modifies the federal final judgment rule, which generally requires that a district court dispose of all issues in a case before any may

1. 28 U.S.C. \& 1292(b) (1958). For discussions of the act, see Green \& Green, A New Elentent in Federal Procedure: Interlocutory Appeals Under the New' Stadule, 45 A.B.A.J. 681 (1959) ; Holtzoff, Interloctutory Appeals in the Federal Courls, 47 Geo. L.J. 474 (1959) ; Wright, The Interlocutory Appeals Act of 1958, 23 F.R.D. 199 (1959); 72 Harv. L. Rev. 584 (1959); 107 U. PA. L. Rev. 859 (1959); 58 Colus. L. REv. 1300 (1958).

2. "Interlocutory' in law, means not that which decides the cause, but that which settles some intervening matter relating to the cause" Taylor v. Breese, 163 F'ed. 678, 684 (4th Cir. 1908).

3. "The term [civil action] was used in the broad sense to distinguish between criminal litigation, on the one hand, and all others . . . . Congress meant to put all civil litigation, without regard to its historical divisions of law, equity, or admiralty, within the reach of the new Act" Continental Grain Co. v. Federal Barge Lines, Inc., 268 F.2d 240, 242 (5th Cir. 1959).

4. See 28 U.S.C. $\S 1291$ (1958) ("the courts of appeals shall have jurisdiction of appeals from all final decisions of the district courts"). A final decision is "one which ends the litigation on the mierits and leaves nothing for the court to do but execute the judgment." Catlin v. United States, 324 U.S. 229, 233 (1945); see Collins v. A[iller, 252 U.S. 364, 370 (1920) ("The rule requires that the judsment to be appealable should be final not only as to all the parties, but as to the whole subject matter and as to all the causes of action involved ...."); 6 MLOore, Federal Practice II 54.04-.05, 54.43 (2d ed. 1953) [hereinafter cited as Moore, Fed. Practice] ; Crick, The Final Judgment as a Basis for Appeal, 41 YaLE L.J. 539 (1932) [hereinafter cited as Crick]; Note, 47 Coluss. L. REv. 239 (1947); Note, 58 YALE L.J. 1186 (1949). 
be considered by a court of appeals. ${ }^{5}$ At the other extreme from a final judgment rule is interlocutory appeal by right, which prevails in New York. But even there only those orders involving "some part of the merits" or affecting "a substantial right" may be appealed.

Many advantages to courts and litigants stem from a strict final judgment rule. It results in fewer appeals than the New York system, since a final judgment below often renders moot or nonprejudicial erroneous interlocutory decisions. $^{7}$ Less court time is said to be consumed by one appeal from it final judgment than by successive appeals from each disputed intermediate order." And limiting review to final decisions wotld enable the appellate court to view the issues in light of a complete record. ${ }^{0}$ Similarly, parties will be benefited if lower-court proceedings are not punctuated by appeals which increase expense ${ }^{10}$ and delay ${ }^{11}$ termination of the controversy.

On the other hand, under a strict final judgment rule, an erroneous interlocutory decision by a trial judge may prolong, rather than expedite, litigation. When the order requires reversal on final appeal, all intervening lower-court proceedings are wasted. ${ }^{12}$ Even when the error would be technically nonprejudicial because the party aggrieved eventually wins below, its correction on interlocutory appeal may, by producing immediate judgment or inducing settlement, save time and money. Additionally, no matter which party is ultimately successful, some interlocutory rulings, such as those ordering production of documents or affecting venue, cause expenses which, once incurred, cannot be regained on review of a final judgment. Aside from its effect on particular

5. 28 U.S.C. $\$ 1292$ (a) (1958) provides for interlocutory appeals in four special situations. See text at notes $45-49$ infra. Direct interlocutory appeals can be taken to the Supreme Court from a district court order holding an act of Congress unconstitutional in a civil suit where the United States is a party, or from a three-judge court order granting or denying an injunction. 28 U.S.C. $\$ \S 1252,1253$ (1958).

6. N.Y. Civ. Prac. Act $\$ 609$; see 6 Carmody, New York Practice $726-44$ (2d cel. 1934).

7. See Perkins v. Endicott Johnson Corp., 128 F.2d 208, 212 (2d Cir. 1942), aff'l, 317 U.S. 501 (1943) ("Only the seriously prejudicial defects will be dignified by appellatc attention [because] ... many mistakes ... will be seen to be trivial from the perspectivc of a final disposition of the case. ..."). A party may lose several interlocutory questions, but still win the law suit. E.g., Countee v. United States, 127 F.2d 761 (7th Cir. 1942) (defendant forced to proceed on erroneous burden of proof but won case).

8. See Catlin v. United States, 324 U.S. 229, 233-34 (1945); 6 Moore, Fed. Practice If 54.41[3], at 265. But cf. Crick 557, 562.

9. See 6 Moore, Fed. Practice $\int$ 54.41[3], at 265.

10. See Forgay v. Conrad, 47 U.S. (6 How.) 201, 205 (1848).

11. See City of Louisa v. Levi, 140 F.2d 512, 514 (6th Cir. 1944). The use of interlocutory appeals as a dilatory tactic has produced criticism of New York practice. See Zalkind v. Scheinman, 139 F.2d 895, 907 n.5 (2d Cir. 1943) (dissenting opinion), ccrt. denied, 322 U.S. 738 (1944); Hearings Before Subcommittee No. 3 of the House Committee on the Judiciary, 85th Cong., 2d Sess., ser. 11, at 9 (1958) [hereinafter cited as Hearings]; cf. Harper \& Atwood, Civil Practice in Federal Courts, in Trtal PuncricF 83 (Practicing Law Institute ed. No. 7 1956).

12. See In re Sylvania Elec. Prods., Inc., 220 F.2d 423, 425 (1st Cir. 1955) ; Hearinlys 8, 19. 
cases, interlocutory review may facilitate prompt appellate determination of important new questions of law. ${ }^{13}$ Moreover, abandonment of a final judgment rule would make moot the litigious issue of defining "final judgment" 14 and could turn the focus of judicial inquiry on the more basic problem-whether an appeal should or should not be heard.

On balance, as the Supreme Court has pointed out, "it is difficult to generalize as to whether interlocutory appeals are or are not advantageous to an efficient administration of justice."15 But the Court's conclusion that recunciliation of conflicting considerations must be achieved by the legislature ${ }^{115}$ was rejected by the enactment of section 1292(b), which subjects the appralability of interlocutory orders to judicial discretion.17 The extent to which the cuurts can utilize 1292(b) to alleviate the disadrantages of the final judgment rule while minimizing the drawbacks of interlocutory appeals is the topic of this Comment.

\section{BaCkgRound of 1292(b)}

The final judgment rule, currently embodied in section 1291 of the Judicial Code, ${ }^{18}$ derives without substantial change from section 22 of the Judiciary: Act of 1789.19 Under section 22, lower court decisions were reviewalble unly: by writ of error. ${ }^{20}$ Principally concerned with actions at law, Congress chuse

13. Cf. 4 MOORE, FED. PRACTICE $\{26.37$ [7], at 1220 (provision for appeal of discovery orders would permit courts of appeals to play constructive role in shaping law of discuvery ).

14. See Crick 557. 28 U.S.C.A. § 1291 has 140 pagres of annotations, at 235-375.

15. Baltimore Contractors, Inc. v. Bodinger, 348 U.S. 176, 185 (1955).

16. Id. at $181,185$.

17. S. REP. No. 2434, 85th Cong., 2d Sess. 3-4 (1958) [hereinafter cited S. Ker.].

Some states allow interlocutory appeal in much the same fashion as $\S 1292(\mathrm{~b})$. Th: closest analogy is N.J. Apr. Drv. R 2:2-3(b), which provides that the Appellate Division "may in its discretion permit appeal ... from an interlocutory order ... when, in the opinion of the court, the grounds for appeal are substantial and the appeal, if sustaincd, will terminate the litigation." See MAss. ANN. Laws ch. 231, § 111 (1932) (judge of Supreme Judicial Court, Superior Court, and land court can in his discretion repiort interlocutory order for consideration of whole court before continuing); MIss. CurE A:s:. $\S 1148$ (1956) (interlocutory appeals in equity permitted in trial judge's diseretiun iur the reason, among others, of avoiding expense and delay); W. VA. Cove Axs. $\S 5783$ (1955) (discretionary interlocutory appeal by certification to supreme court); Iowa R. CIV. P. 332 (appeal allowed when the Supreme Court finds that an order involves "substantial rights and will materially affect the final decision, and that a determination of its correctness before trial on the merits will better serve the interests of justice").

In Great Britain, appeal can be taken from interlocutory orders in the discretion of either the judge of first instance or the Court of Appeal. Judicature Act, 1925, 15 \& 16 Geo. 5, c. 49, §31(1) (i); see Burnand, Diansond \& Burnett-Hall, Annual Priltill. 1956 order 58, rule 1, at 1236 ("Appeal With Leave Only A.3.") ; OdGers, Plesidic \& Practice 359-60 (1955).

18. 28 U.S.C. § 1291 (1958).

19. Ch. 20, I Stat. 84; see Baltimore Contractors, Inc. v. Bodinger, 348 U.S. 17t, 178-79 (1955) (tracing evolution of final judgment rule from $\$ 22$ ).

20. Section 22 governed both review of decisions of the circuit courts-the base line federal law and equity tribunals, Judiciary Act of 1789, ch. 20, $\$ 11,1$ Stat. 78-79; Moore \& 
this mode of review, which restricts appellate consideration to legal questions, in order to safeguard jury verdicts. ${ }^{21}$ Congress further provided that the writ would lie only after a final judgment or decree.22 In Baltimore Contractors, Inc. v. Bodinger, ${ }^{23}$ the Supreme Court viewed section 22's final judgment rule as a legislative policy decision on the wisdom of interlocutory review. ${ }^{24}$ When applied to law cases, however, it may also be explained as a codification of a traditional writ-of-error requirement which, in turn, was based on the ancient "conception that the record cannot be in two courts at once . . .." While section 22's adoption of this common-law limitation in equity cases represented a break with English practice, ${ }^{26}$ this may have been as much a product of distrust of chancery ${ }^{27}$ and, perhaps, desire for a uniform basis for appellate jurisdiction as of disfavor of interlocutory review.

Vestal, Present and Potential Role of Certification in Federal Appellate Procedurc, 35 VA. L. Rev. 1, 10-11 (1949) - by the Supreme Court, see Blaine v. The Ship Charles Carter, 4 U.S. (4 Dall.) 22 (1800), and decisions of the district courts by the circuit courts. District courts were primarily admiralty and petty criminal tribunals. Their civil jurisdiction was limited to forfeitures under federal laws, suits in tort by aliens under the laws of nations or a treaty, common law suits by the United States when less than $\$ 100$ was involved, and suits against consuls. Ch. 20, $\$ 9,1$ Stat. 76-77. Two of the more remote district courts-for Kentucky and Maine-were also vested with circuit court original jurisdiction. Ch. 20, $\S 10,1$ Stat. 77-78. Appeal replaced writ of error only in the instance of circuit-court review of district-court admiralty decisions. Ch. 20, $\$ 21,1$ Stat. 83-84.

In 1803 Congress provided for appeal of final judgments from circuit courts to the Supreme Court in equity and admiralty cases, but in equity it remained "subject to the same rules ... as are prescribed in law in case of writs of error." Act of March 3, 1803, ch. 40, § 2, 2 Stat. 244; see Warren, Neze Light on the History of the Fedcral Judiciary Act of 1789, 37 Harv. L. Rev. 49, 102-03 (1923) (purpose was to extend Supreme Court review in equity and admiralty cases to facts as well as law).

The present system of courts of appeals was not instituted until 1891. See note 39 infra and accompanying text.

21. Warren, supra note 20, at 102-03; see Dower v. Richards, 151 U.S. 658 (1894).

22. Judiciary Act of 1789, ch. 20, § 22, 1 Stat. 84 .

23. 348 U.S. 176 (1955), 69 Harv. L. Rev. 190, 54 MrCR. L. Rev. 136.

24. 348 U.S. at 178.

25. See Crick 541-44.

Moreover, the early cases cited in Bodinger as denouncing "fragmentary appeals," 348 U.S. at $178 \mathrm{n} .3$, are not concerned with interlocutory review's typical characteristic of settling different aspects of a suit on successive appeals. Canter v. American Ins. Co., 28 U.S. (3 Pet.) 306, 318 (1828), affirmed a circuit court decree because appellant failed to appeal the order complained of when it was entered; United States v. Bailey, 34 U.S. (9 Pet.) 265, 273 (1835), denied a circuit court attempt to cortify a whole case to the Supreme Court. In Canter the Court was concerned with the need for prompt appeal so as to bring litigation to a close within a reasonable time. In Bailey the Court was controlling its certification jurisdiction by preventing the circuit courts from avoiding their duty to decide cases when possible rather than passing them on to the Supreme Court.

26. See Forgay v. Conrad, 47 U.S. (6 How.) 201, 205 (1848) ; Crick 547.

27. See Fiemd \& Kaplan, Materials on Civil Procedure 296-97 (1953); Warren, supra note 20, at 96; cf. Judiciary Act of 1789, ch. 20, § 16, 1 Stat. 82. 
Moreover, under English chancery practice, interlocutory appeals were cunducted within the same court or at least in the same city, ${ }^{23}$ while similar Supreme Court review would entail a time-consuming trip to Washington." And since two Justices sat on each circuit, ${ }^{30}$ an interlocutory appeal to the full sixmember Court might have seemed futile. ${ }^{31}$ Finally, the view expressed in Bodinger that "from the very foundation of our judicial system" Congress wished "the whole case and every matter in controversy in it decided in a single appeal"32 seemingly disregards the Judiciary Act of 1802 and its case law. This act, which reduced the circuit courts to two members, ${ }^{33}$ provided that "whenever any question shall occur ... upon which the opinion of the judges shall be opposed, the point upon which the disagreement shall happen, shall ... upon the request of either party" be certified to the Supreme Court. ${ }^{34}$ And review by certification under this statute was, in effect, completely limited by the Court to interlocutory questions :35 "a single and material point" would be decided but not questions decisive of the "whole cause."so

During the nineteenth century, the Supreme Court occasionally relased

28. If a case was originally heard by the Miaster of the Rolls it cuuld be reviewed by the Chancellor. Appeal then could be taken to the House of Lords, if it consented. Crict: $546-47$.

29. See 3 Beveripge, Life of Johx Marshall 55 (1919); 1 Warren, The Suprese Court in United States History 86 (1922).

30. Judiciary Act of 1789 , ch. 20, \& 4, 1 Stat. 74-75.

31. See $1 W_{\text {ARREN, }}$ op. cit. supra note 29 , at 86 (citing views of the first AtturneyGeneral, Edmund Randoiph). An obstacle to impartial review was partially removed when one of the two Supreme Court Justices sitting on each circuit court was replaced by a district judge. Act of March 2, 1793, ch. 22, $\$ 1,1$ Stat. 333. After 1808, district judges, sitting alone, customarily constituted circuit courts. Brown, The Ncal Federal Judicial Code, 73 CeNr. L.J. 275, 279 (1911).

32. 348 U.S. at 178 , quoting with approval MicLish v. Roff, 141 U.S. 661, $005-64$ (1891).

33. Act of April 29, 1802, ch. 31, § 4, 2 Stat. 156.

34. Act of April 29,1802, ch. 31, 6,2 Stat. 156 .

Even prior to the act of 1802, a limited type of interlocutory appeal existed. When Congress in 1793 provided that a single Supreme Court Justice plus a district court judge might constitute a circuit court, it also supplied a method for resolving a 1-1 deadlock on any plea to the jurisdiction. The action would be continued to the next succeeding session when a different Supreme Court Justice would sit on the court; in the event of another equal division, the presiding Justice's opinion would prevail. Act oi March 2, 1793, ch. 22, § 1, 1 Stat. 333.

35. The very term "interlocutory" was early used in this context. Ogle v. Lee, 6 U.S. (2 Cranch) 32 (1804).

36. White v. Turk, 37 U.S. (12 Pet.) 236 (1838) (certification of validity of bond posted on a judgment involved validity of entire judgment, review refused); accord, Saunders v. Gould, 29 U.S. (4 Pet) 392 (1830) (on certification of question of propert statutory construction, Court remanded because it found that the circuit judges were divided on all points); cf. United States v. Daniel, 19 U.S. (6 Wheat.) $5+2$ (18211 (certification cannot be made of new trial order by lower court). But sec Jones $Y$. Van Zandt, 46 U.S. (5 How.) 215, 223 (1847) (certification of fourteen questions accepted by Supreme Court). 
somewhat the definition of "finality." 37 But any tendency to broaden appellate jurisdiction was kept within narrow bounds by the practical problems of increased activity of the Justices, both on circuit and on the Court. ${ }^{38}$ Not until the creation of intermediate appeal courts in $1891^{30}$ did appreciable judicial and legislative modifications of the final judgment rule become feasible.

The courts have held "final" for purposes of appeal "collateral" orders which substantially prejudice a party's rights regardless of the suit's ultimate outcome-such as those denying security or intervention.40 Additionally, when a prejudicial interlocutory order cannot be deemed final, prerogative writs have been allowed on the theory that no other remedy exists. ${ }^{41}$ But these writs are not generally available as a device for interlocutory review $;^{42}$ their use is ordinarily limited to situations where the appellate court can be said to act in aid of its jurisdiction. ${ }^{43}$ Through the Federal Rules of Civil Procedure, the Supreme Court has partially accommodated the final judgment principle to modern practice. ${ }^{44}$ Rule $54(\mathrm{~b})$ allows the district judge in a multiclaim

37. See Forgay v. Conrad, 47 U.S. (6 How.) 201, 205 (1848) (decree requiring delivery of land and slaves prior to determination of title); Bronson v. Railroad Co., 67 U.S. (2 Black) 524, 531 (1862) (decree allowing recovery of one-half claim when plaintiffs had moved to reopen case to recover full claim); Williams v. Morgan, 111 U.S. 684 (1884) (decree of foreclosure fixing compensation for trustee is final for appeal prior to disposition of full proceedings).

38. The finality provisions of the Judiciary Act of 1789 drew more praise as the work load of the Justices grew. See Frankfurter \& LANdis, The Business of tile Supkem: CouRT 49-52, 60 (1928); Crick 551.

39. Judiciary Act of 1891 , ch. 517,26 Stat. 826.

40. See, e.g., Cohen v. Beneficial Industrial Loan Corp., 337 U.S. 541, $546-47$ (1949) (order denying security); Perlman v. United States, 247 U.S. 7 (1918) (order allowing district attorney to take custody of witness's exhibits in civil suit for use against him in criminal prosecution); Clark v. Taylor, 163 F.2d 940, 947-48 (2d Cir. 1947) (disscnting opinion of Frank, J.) (collecting cases).

[A]n order is final ... which settled substantial rights; ... which is designed to be operative in a way affecting such rights at once or before or irrespective of the final decree in the main litigation. ... [quoting Rector v. United States, $20 \mathrm{r} .2 \mathrm{dl}$ 845, 872 (8th Cir. 1927)] [T] here may be one or more final decisions on particular phases of the litigation .... [quoting Rubert Hermanos, Inc. v. Puerto Rico, 118 F.2d 752, 757 (1st Cir. 1941)].

Kasishke v. Baker, 144 F.2d 384, 386 (10th Cir. 1944). See generally 6 Moore, Fed. PracTICE II 54.14; Underwood, Appeals in the Federal Practice From Collateral Orders, 36 VA. L. REv., 731-36 (1950).

41. Note, 63 YALE L.J. 105 (1953).

42. See Ex parte Fahey, 332 U.S. 258 (1947); Roche v. Evaporated Milk Ass'n, 319 U.S. 21 (1943) ; Ex parte Roe, 234 U.S. 70 (1914); Ex partc Whitney, 38 U.S. (13 Pet.) 404 (1839).

43. 28 U.S.C. $\$ 1651$ (1958), see, e.g., Foster-Milburn Co. v. Knight, 181 F.2d 949 (2d Cir. 1950) (venue). But LaBuy v. Howe Leather Co., 352 U.S. 249, 259 (1957) (5-4 decision), suggests that the extraordinary writs can also be used to supervise the lower courts.

44. See Panichella v. Pennsylvania R.R., 252 F.2d 452, 454 (3d Cir. 1958) ; 6 MLookE, Fed. Practice \I 54.23[1]. 
suit to enter judgment on one or more but less than all claims when he determines that no just reason for delay exists.

Four congressional exceptions modified the final judgment rule prior to the adoption of section 1292(b). Two originated in the same decade as the courts of appeal, ${ }^{45}$ two a quarter of a century later ;0 unsupplemented since 1927 , the group is codified, in order of enactment, in section 1292(a) of the Judicial Code. Section 1292(a) permits appeal from interlocutory decisions: (1) granting or denying preliminary injunctions ; $^{\mathbf{7}}$ (2) creating or continuing receiverships; (3) determining rights and liabilities in admiralty cases, such as a finding of liability prior to assessment of damages; 48 (4) adjudging an infringement in patent cases before an accounting. ${ }^{40}$ An allowance of interlocutory review in the two earlier situations seems motivated by the order's effect on a party's conduct outside the courtroom; in the latter two, by its expense-producing impact on the proceedings in court. Thus the immediate effect of an order determining liability in admiralty or patent cases is further proceedings to determine damages. Since proof of these would often be protracted, interlocutory appeal ensures that the time and cost of assessing damages will be expended only after liability can no longer be challenged.00 These admiralty and patent appeals are the historical precursors of section 1292(b), whose congressional consideration reveals a similar aim for economy in litigation. ${ }^{51}$

Section 1292 (b) is an enactment of a proposal submitted to Congress by the Judicial Conference of the United States 62 to "improve and expedite the administration of justice in the courts." 53 It was adopted without debate on the

45. 28 Stat. 666 (1895), as amended, 28 U.S.C. $\$ 1292$ (a) (1) (1958) (injunetive orders) ; 31 Stat. 660 (1900), as amended, 28 U.S.C. $\S 1292$ (a) (2) (1958) (receiverships).

46. 44 Stat. 233 (1926), as amended, 28 U.S.C. $\$ 1292$ (a) (3) (1958) (admiralty); 44 Stat. 1261 (1927), as amended, 28 U.S.C. \& 1292(a) (4) (1958) (patents).

47. Certain stays and related orders have been construed as enjoining prosecution of an action at law. See cases cited infra note 181. Compare Federal Glass Co. v. Loshin, 217 F.2d 936 (2d Cir. 1954) (allowing appeal), with Miorgenstern Chem. Co. v. Sehering Corp., 181 F.2d 160 (3d Cir. 1950) (denying appeal).

48. See 6 Moore, Fed. Practice [f 54.06[5], at 38.

49. In addition, federal courts when sitting as courts of bankruptcy can entertain interlocutory appeals in bankruptcy cases under the Bankruptcy Act $\$ 24,30$ Stat. 5.t

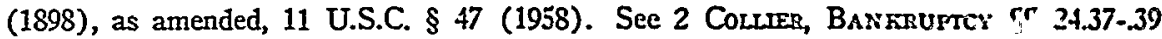
(14th ed. Moore 1956).

50. See Hearings 19; Moore, Codrsentary on the Judicul Code 4SS (1948); ef. Chace v. Vasquez, 24 U.S. (11 Wheat.) 429 (1826) (pre-1292(a) admiralty case).

51. Compare H.R. REp. No. 1667, 85th Cong., 2d Sess. 1 (1958) [hereinafter cited as H. Rep.] ; S. Rep. 2-3, and Hearings 8-9, 19, with H.R. REp. No. 383, 69th Cong., 1st Sess. (1926) (admiralty), and S. Rep. No. 1319, 69th Cong., 2d Sess. (1927) (patents).

52. Letter From Elmore Whitehurst, Acting Director of the Administrative Office of the United States Courts, to Hon. Sam Rayburn, Speaker of the House of Rerresentatives, March 15, 1957, in Hearings 23.

53. Hearings 7 (testimony of Hon. John J. Parker, Chief Judge of the Fourth Circuit, and Chairman of the Judicial Conference's Committee on Appeals From Interlocutory Orders of the District Courts). 
basis of recommendations in committee reports and hearings. ${ }^{54}$ These evinced a general concern with circumstances in which the final judgment requirement caused "proceedings, perhaps prolonged to no avail." The more specific legislative design is best revealed in four situations the bill's proponents instanced as suitable for interlocutory appeal: (1) Cases in which a long trial results from a pretrial order erroneously overruling "a defense going to the right to maintain the action," "se such as statute of limitations, ${ }^{\text {,7 }}$ or lack of jurisdiction $; 88$ (2) any suit involving prolonged assessment of damages after determination of liability, such as accounting in contract ${ }^{50}$ or damages in antitrust; ${ }^{60}$ (3) cases where the disposition of motions for impleader might induce voluntary nonsuit or settlement; ${ }^{61}$ (4) suits where venue is transferred allegeclly without proper authority. ${ }^{62}$ Beyond these examples the intended scope of the legislation is less clear. ${ }^{63}$ Aware of the need to avoid fruitless litigation without encouraging dilatory appeals, ${ }^{64}$ the draftsmen made the use of 1292 (b) in any given case dependent on the "wisdom of the judges" out of four, since the district judge and a majority of the court of appeals must concur in each application. ${ }^{66}$ They are to weigh not only the convenience of litigants in a particular case, but also the benefits which would derive for courts and litigants in general from facilitating judicial administration. ${ }^{07}$ While use of the phrase "exceptional cases" in the legislative history ${ }^{68}$ suggests that the

54. See 104 Cong. Rec. 7665, 8002, 8125, 18062, 18629, 18928, 18992, 19264 (1958).

55. Letter From Elmore Whitehurst, stipra note 52.

56. Hearings 8 (testimony of Judge Parker); H. REP. 2.

57. Ibid.; Hearings 8.

58. S. REP. 2.

59. Hearings 8; cf. Jessup \& Moore Paper Co. v. Bryant Paper Co., 283 Pa 434, 129 At1. 559 (1925) (affirming existence of contractual liability on basis of trial court's preliminary ruling), aff'd on appeal from final judgment, $297 \mathrm{~Pa} .483,147$ Atl. 519 (1929) (affirming determination of damages, which required extensive proceedings and expert testimony).

60. Hearings 9.

61. Ibid.

62. Ibid.

63. "[I]t is impossible to foresee the various types of cases that might arise." Hcarings 18 (testimony of Judge Parker).

64. S. REP. 2-3; H. ReP. 1, 2; Hearings 10-11, 19, 24.

65. S. REP. 4.

66. The courts of appeals usually sit in three-member panels, but there may be more. See, e.g., Milbert v. Bison Labs., Inc., 260 F.2d 431 (3d Cir. 1958) (en banc hearing on 1292 (b) application).

67. S. REP. 2-4; Hearings 7 (testimony of Judge Parker).

68. See H. REp. 2 ("Your committee adopts with approval the view . . . that appeals under this legislation should only be used in exceptional cases where an immediate appeal may avoid protracted and expensive litigation and is not used or granted in ordinary litigation wherein the issues raised can otherwise be properly disposed of." (Emphasi added.)) ; Report to the Judicial Conference of the Tenth Circuit, in Hcarings 13, 14; Letter From Elmore Whitehurst, sitpra note 52; Hearings 20 (testimony of Hon. Albert B. Maris, Judge of the Fourth Circuit). The "exceptional case" language was first used in Comm. on Appeals From Interlocutory Orders of the District Courts, Report, Sept. 
statute applies only to the "big" case, ${ }^{60}$ emphasis was also given to 1292 (b)'s ameliorating effect on district court backlogs, ${ }^{70}$ a result obtainable only if the new section is more liberally employed. ${ }^{11}$

\section{ANALYsis of 1292(b): In GeNernL}

Appeal under section 1292(b) is conditioned upon meeting three major statutory requirements. The order must, in the "opinion" of the district judge, (1) involve a "controlling question of law," (2) offer "substantial ground for difference of opinion" as to its correctness, (3) be able, if immedintely. appealed, to "materially advance the ultimate termination of the litigation." After satisfying these criteria at the district court level, the order is subjected to an undefined discretionary test by the court of appeals. The three criteria do not limit the order to any specific type, except for excluding 1292(a) orders. $^{72}$ They are not to be read so broadly that the district court can allow appeal whenever it would promote the "efficient administration of justice," since the Judicial Conference draftsmen deliberately rejected this phraseology in favor of a more restricted wording. ${ }^{73}$ Every refusal to certify an order "not otherwise appealable" should be grounded on failure to meet a specified one or more of the three criteria; every grant, on finding all three fulfilled. ${ }^{78}$ Although the tests are often interrelated in application-for example, the more substantial a difference of opinion and the more clearly controlling the question, the more likely the ultimate termination will be advanced by appeal-no substitute exists for an initial, independent, consideration of each.

The "substantial ground for difference of opinion" test requires the district judge to determine whether arguments against his order have merit. ${ }^{25}$ In

23, 1953, in Hearings 12-13, which described the opposite of the "exceptional case" as "ordinary litigation which could otherwise be promptly disposed of." (Emphasis added.) The Committee was, therefore, apparently only saying that many cases would not meet the "materially advance" requirement, and not limiting $1292(b)$ to "big" cases. See note 91 infra and accompanying text. Similarly, by substituting "properly" for "promptly," the House Report was probably only saying that many cases would not meet the "substantial ground for difference of opinion" test, since the district judge could "properly" dispose of them without appeal.

69. See Oskoian v. Canuel, 264 F.2d 591, 594 (1st Cir. 1959); Mfilbert v. Bison Labs., Inc., 260 F.2d 431, 433 (3d Cir. 1958); Bobolakis v. Compania Panamena Maritima San Gerassimo, S.A., 168 F. Supp. 236, 239 (S.D.N.Y. 1958), 58 Coluss. L. REv. 1306 (critical of decision); Kroch v. Texas Co., 167 F. Supp. 947, 949 (S.D.N.Y. 1958).

70. See S. REP. 4; 104 CoNG. REc. 8002 (1958) (remarks of Representative Keating).

71. See Wright, The Interlocutory Appcals Act of 1958, 23 F.R.D. 199, 205 (1959); 58 COLUM. L. Rev. 1306, 1310 (1958) ; 107 PA. L. Rev. 859, 864 (1959),

72. These would be "otherwise appealable under this section." Of course, "collateral" orders appealable as "final" under 1291 are not "interlocutory," and therefore are beyond the scope of 1292(a) or (b). See Wright, supra note 71, at 203.

73. Hearings 10-11.

74. "We think we have safeguarded this interlocutory appeal sufficiently" to authorize the broadening of the right." Hearings 11 (testimony of Judge Parker). See also 104 ConG. REC. 8002 (1958) (remarks of Representative Keating).

75. See note 68 supra. 
cases of first impression, this could be accomplished only by evaluating the logic and policy behind the competing view; but when precedent exists, it ton must be weighed. ${ }^{70}$ If the district judge's order runs counter to the weight of precedent, a finding of "substantial ground for difference of opinion" must be made. If precedent clearly supports his position, appeal should be denied, in the absence of other authority tending to show that precedent will be overruled. Should the weight of precedent be equally divided, as when circuits are in conflict, the statutory criterion is met by its very terms. The Southern District of New York, however, has held, in a case in which it followed Second Circuit precedent, that since its court of appeals had rejected the contrary holdings of other circuits and since the Supreme Court was unlikely to resolve the dispute via certiorari, no "substantial ground for difference of opinion" existed." This view, which interprets the requirement in terms of the possibility of immediate reversal, muddies the statutory criteria by making "difference of opinion" dependent upon a factual determination that the Supreme Court would not agree to review the question-a determination more appropriate to a refusal to grant an appeal under these circumstances because it would not "materially advance the ultimate termination of the litigation."78 Denial of certiorari may depend upon factors other than the Supreme Court's acquiescence on the merits. ${ }^{79}$

The concept of "controlling question of law" must encompass, at least, every order which, if erroneous, would constitute reversible error on final appeal. The order need not also be determinative of plaintiff's claim on the merits, since dismissal for want of jurisdiction was clearly contemplated as within 1292 (b).$^{80}$ Nor must such reversal terminate the litigation, since in two of the sponsors' examples, impleader and transfer of venue, the suit could continue regardless of the interlocutory appellate determination. ${ }^{81}$ A more difficult problem is whether a question is controlling when error would not be reversible after judgment. Neither Committee nor Conference eviclenced an intent that such questions be per se not appealable. In fact, immediate reversal

76. The test of whether stare decisis has made a once-arguable question insubstantial should be similar to that employed by the Supreme Court in determining whether a fecteral question appealed from a state court is "substantial" or foreclosed by prior holdings. See, e.g., Equitable Life Assur. Soc'y v. Brown, 187 U.S. 308, 311 (1902); Manhattan Life Ins. Co. v. Cohen, 234 U.S. 123, 136-37 (1914) ; Patterson v. Stanolind Co., 305 U.S. 376 (1939). See generally Robertson \& KirkhaM, Jurisdiction of the Supreate CouitT of THE UNited States $\$ 58$ (2d ed. Wolfson \& Kurland 1951).

77. Berger v. United States, 170 F. Supp. 795 (S.D.N.Y. 1959).

78. Strangely enough, the court held that this requirement had been met. Id. at 796 .

79. See Robertson \& Krrkhan, op. cit. supra note 76, at 316; STERn \& Gressman, Supreme Court Practice 103-30 (2d ed. 1954).

Another district court confronted with apparent intercircuit conflict wrongly concluded that the issue thereby became a "controlling question of law." See Corabi v. Auto Racing, Inc., 264 F.2d 784 (3d Cir. 1959).

80. S. REP. 2.

81. See Hearings 9 (testimony of Judge Parker). 
of error in these questions may result "in a saving of the time of the district court and considerable expense on the part of the litigants."B2 For example, a transfer, or refusal to transfer, venue on forum non conveniens ground will ordinarily not be reversed after judgment, ${ }^{83}$ but may well increase the costs of prosecuting or defending a suit. 84 To read "controlling" as "serious to the conduct of the litigation, either practically or legally" 85 will not undermine the statute's built-in safeguards against abuse and delay, since only those appeals which "may materially advance the ultimate termination of the litigation" would be allowed. Indeed, this use of the word "controlling" bolsters the latter requirement by ensuring that the question of "material advancement" be decided in terms of the case at bar, rather than in the abstract.

The requirement that interlocutory appeal "may materially advance the ultimate termination of the litigation" is the most basic in 1292 (b). The aim of the section is to create those benefits for parties and courts which stem from abbreviating the litigation process. This, in turn, demands a skillful balancing of many factors by the district judge. Ordinarily termination will be advanced only when the appellate court reverses his order, though affirmance can have the same effect where the losing party has no remaining points for subsequent appeal. But the statute does not place the district judge in the position of predicting that he will be reversed; thus he need only certify that the appeal may hasten the litigation. ${ }^{88}$ Reversal on appeal of a "controlling question" may advance the termination of the suit in three ways: By leading directly to the entry of final judgment (or voluntary dismissal) upon remand, by preventing a reversible error which would require an entire new trial, or by preventing error which, while not reversible, protracts the litigation..$^{87}$ Whether such saving of time would be "material" in a particular case depends initially on the stage the proceedings have reached at the time of the interlocutory order. For example, a motion to dismiss the complaint with prejudice must be made within twenty days ${ }^{88}$ and appeal from a prompt denial may save almost an entire suit below; ${ }^{89}$ on the other hand, when an order refusing a directed verdict is entered on the verge of final judgment, immediate appeal will hardly

82. See S. Rep. 2; 4 Míore, Fm. Practice II 26.37[6].

83. "Application of the doctrine of formm non conzeniens is entrusted to the diseretion of the District Courts to be exercised upon equitable considerations, and its determination may not be disturbed upon appeal except for a clear abuse of this discretion." Hopson v. Hopson, 221 F.2d 839, 842 (D.C. Cir. 1955); see Pilot Life Ins. Co. v. Boone, 236 F.2d 457, 462 (5th Cir. 1956) ; cf. Note, 67 Yale L.J. 122, 124 (1957).

84. This example, however, will ordinarily fail to meet the "difference of opinion" test. See text at note 141 infra.

85. See Hearings 21 (testimony of Judge Miaris).

86. Hearings 18 (testimony of Judge Mfaris).

87. Cf. 4 Moore, Fed. Practice If 26.37[6].

88. FED. R. CTv. P. 12(a).

89. Most denials of rule 12 motions should not be certified, however, since "substantial grounds for difference of opinion" will probably not exist; the appellate court would doubtless respect the district judge's efforts to give plaintiff an opportunity to state his case. See notes 159-64 infra and accompanying text. 
accelerate the proceedings. Once the district judge determines that, on the trial level, a significant amount of time will be saved, he should consider whether this time would have been devoted to active preparation and trial, ${ }^{00}$ or whether, in his opinion, plaintiff has an unusually great need for swift compensation. If not, the advancement of the litigation by interlocutory appeal probably would not be "material." 01 Additionally, the appeal's time and cost,"2 and its disruptive effect on the proceedings below, must be weighed since both can detract from the materiality of any advance in litigation, ${ }^{33}$ especially when errors not reversible on final appeal are involved. Of course, an appeal which the district judge believes a party would take only for purposes of delay cannot be said materially to advance the litigation. ${ }^{04}$ Finally, since the benefit of certification is realized only if the appeal is permitted and expeditiously disposed of by the appellate court, the "materially advance test" will not be met when the state of the court of appeals' docket, ${ }^{95}$ or its past performance on similar questions, makes disapproval of the application for appeal or delay of decision fairly certain.

Section 1292(b) grants the court of appeals discretion, unqualified by statutory criteria, to permit or deny the interlocutory appeal. ${ }^{06}$ The court may, of course, refuse appeal when it finds erroneous the district court's determination that $1292(\mathrm{~b})$ 's requirements have been met. ${ }^{07}$ While the appellate court

90. An effective pretrial conference should enable the district judge and the parties to ascertain these facts, as well as what questions of law may be "controlling."

91. Such a requirement that time saved, in order to be "material," must be important in terms of the activity of trial court and counsel or of the parties' human needs, may have been the basis of the Judicial Conference committee's statement that the statute "shall and will be used only in exceptional cases," and not "ordinary litigation." Comm. on Appeals from Interlocutory Orders of the District Courts, Report, Sept. 23, 1953, in Hearings 12. "Exceptional cases" were further described as those presenting the possibility of "protracted and expensive litigation"; "ordinary litigation" as litigation "which could otherwise be promptly disposed of." Ibid. If the words "protracted" and "promptly" are both given their fullest meanings, a large group of cases exist which fall in neither category - which neither are "protracted," i.e., lasting an extremely long time, or "promptly disposed of," i.e., over extremely soon. Thus the Committee's "exceptional" case may mean only the case in which an interlocutory appeal will save "fruitless" activity. See Hearings 19 (testimony of Judge Maris). See also note 68 supra.

92. Costs of an interlocutory appeal might be allocated between the parties according to the benefits each stands to receive, in a fashion similar to that used by the courts when assessing discovery costs. See, e.g., Gibson v. International Freighting Corp., 8 F.R.D. 487 (E.D. Pa. 1947), aff'd, 173 F.2d 591 (3d Cir. 1949); Winograd Bros., Inc. v. Chase Bank, 31 F. Supp. 91 (S.D.N.Y. 1939) ; Continental Cas. Co. v. Houdry Process Corp., 18 F.R.D. 75 (E.D. Pa. 1955).

93. Cf. Note, 68 Yale L.J. 964, 977 n.63 (1959).

94. S. REP. 3.

95. Hearings 21.

96. "The Court of Appeals may thereupon, in its discretion, permit an appeal . . . ." 28 U.S.C. $\$ 1292$ (b) (1958); see Hearings 21.

97. To facilitate appellate consideration, when multiple grounds are urged in support of a motion, and 1292(b) appeal is permitted from the order thereon, the district 
might be in the best position to evaluate whether an order involves a "controlling question of law as to which there is a substantial ground for difference of opinion," it should be reluctant to overturn the lower court's view that immediate appeal might "materially advance the ultimate termination," since the trial judge "knows all about what ... [the parties] are up to." appeals court may also decline review of properly certified questions because of such factors as the crowded state of its docket compared with the district court's, ${ }^{99}$ the unsuitability of a particular case for deciding the question presented, the preferability of deferring the question until final appeal, ${ }^{100}$ and the unimportance of the issue. ${ }^{101}$ Conversely, the opposite factors would encourage a favorable exercise of discretion, especially when the court is anxious to resolve an issue which might not be raised on final appeal. Before the House Judiciary Subcommittee, Judge Maris, representing the Judicial Conference, analogized the exercise of the appellate discretion under 1292(b) to that of the Supreme Court on certiorari petitions. ${ }^{102}$ The comparison is apt, insofar as the appellate court may decline review without reference to the merits of the question. But it should not follow that the court of appeals need adhere to the ordinary Supreme Court practice of giving no reason for refusing review. ${ }^{103}$ Unlike the Supreme Court, it cannot avoid appeal of the question later in the same case, so that if its denial of the application in fact amounts to an affirmance on the merits, it should so state, in order to indicate whether appeal of the issue after final judgment would be fruitless. ${ }^{104}$ In this way, the statutory goal of avoiding unnecessary proceedings would be effectuated. The same end could be accomplished by imitating the Supreme Court practice of simultaneously entertaining appeal and affirming without opinion, ${ }^{105}$ but such practice is subject to criticism for deciding the case without argument and for affording little, if any,

judge, rather than simply state that he has found that the statutory requirements exists, as was done below in United States v. Woodbury, 263 F.2d 784, 786 (9th Cir. 1959), should indicate which grounds present a "controlling question of law as to which there is a substantial ground for difference of opinion," as was done below in Oskoian y. Canuel, 264 F.2d 591, 593 (1st Cir. 1959).

98. Hearings 11 (testimony of Judge Parker).

99. Hearings 21 (testimony of Judge Mfaris).

100. See Kroch v. Texas Co., 167 F. Supp. 947 (S.D.N.Y. 1958); Gottesman v. General Motors Corp., 268 F.2d 194 (2d Cir. 1959).

101. See Hearings 21; of. District of Columbia v. Sweeny, 310 U.S. 631 (1940).

102. Hearings 21.

103. See Robertson \& Kirkhans, Jurispiction of the Supreare Court of tae United States \$ 316 (2d ed. Wolfson \& Kurland 1951).

104. Judge Maris indicated that, as when the Supreme Court denies certiorari, the court's reasons for denial of an application for appeal would not be known bejund the fact that it considered the appeal untimely. Hearings 21. The Supreme Court, however, has on occasion given its reasons for denying certiorari. E.g., United States ex rel. Schirrmeister v. Watkins, 337 U.S. 942 (1949) ; McKay v. Foster, 332 U.S. 783 (1947); Mason v. Webb, 323 U.S. 747 (1944).

105. Note, 69 HARv. I. Rev. 707 (1956) (collecting cases); see United States : Lane Motor Co., 344 U.S. 630 (1953) (simultaneous grant of certiorari and affirmance). 
guidance to the lower courts. ${ }^{106}$ Moreover, rendering opinions seems necessary to direct the district courts' administration of the new section. ${ }^{107}$

When a district court refuses to certify a question, a court of appeals woul. 1 seem unable to review such action, even if it is contrary to the circuit's usual policy on section 1292(b). The lower court's refusal of certification woulcl not be an appealable final decision. ${ }^{108}$ Conceivably, refusal to certify is itself an appealable interlocutory order. But it would be novel for a judge to deny certification of a question, but still be willing to certify his refusal. Hence, to deem a denial of certification a 1292(b) interlocutory order would be to permit refusals to certify indefinitely to mount one upon another. While theoretically mandamus would lie to compel certification in aid of the circuit court's appellate jurisdiction, ${ }^{109}$ it is available only to compel a judge to perform his duty of forming an opinion on appealability, which presumably he has already done. ${ }^{110} \mathrm{~A}$ possible solution is to review by mandamus the validity of the dis. trict court's uncertified order, rather than of its ruling against certification. But this remedy would be limited to orders traditionally reviewable by mandamus, and even then could be used only if courts reject the contention that section 1292(b) bars the use of extraordinary writs. ${ }^{111}$ Should the circuit court prevent appeal of a certified order by denying the section $1292(\mathrm{~b})$ application, its decision is not always immune from review, even in the absence of abuse of discretion which may lead to Supreme Court mandamus. ${ }^{112}$ When the application is denied on the ground that the district judge misconstrued section 1292 (b), certiorari should lie to review the question of statutory interpretation.

Once the court of appeals has permitted and determined a 1292 (b) appeal, its decision may be reviewed on certiorari.113 Although the exercise of St1preme Court jurisdiction over non-1292(b) interlocutory decisions has been

106. See Brown, Foreward: Process of Laze, The Supreme Court, 1957 Term, 72 Hanv. L. REv. 77 (1958); Note, 69 Harv. L. Rev. 707 (1956).

107. See United States v. Woodbury, 263 F.2d 784 (9th Cir. 1959); In the Matter of Heddendorf, 263 F.2d 887 (1st Cir. 1959).

108. See 72 Harv. L. Rev. 584, 585 (1959).

109. Cf. 6 Moore, Fep. Practice $\llbracket$ 54.41[3], at 267.

110. Mandamus under 28 U.S.C. $\$ 1651$ (1952) lies to review the failure of a lower court to exercise discretion granted to it or to correct any abuse of its discretion when the abuse impinges on the appellate court's jurisdiction. See LaBuy v. Howes Lenther $C_{0}$, 352 U.S. 249 (1957).

111. These, the argument runs, are available under the All-Writs Statute, 28 U.S.C. $\$ 1651$ (a) (1958), only when no remedy by appeal exists, and are thercfore limited pro tanto by the enactment of 1292 (b). See American Oil Co. v. United States, 27 U.S.L. WeEk 3289 (D.C. Cir. Feb. 6, 1959) (summary of issue), cert. denied, 359 U.S. 987, petition for leave to file writ of mandamus denied, 359 U.S. 991 (1959). Ex parte Watkins, 260 F.2d 548 (5th Cir. 1958) ruled that mandamus will be unavailable before a $1292(\mathrm{~b})$ appeal is denied.

112. See Bankers Life \& Cas. Co. v. Holland, 346 U.S. 379, 383 (1953); Virginia v. Rives, 100 U.S. 313, 323 (1879). A refusal of the court of appeals to allow application for appeal under $\S 1292(\mathrm{~b})$ might thus be remedied by mandamus when discretion was abused. Cf. House v. Mayo, 324 U.S. 42 (1945).

113. See 28 U.S.C. § 1254 (1) (1958). 
occasionally accompanied by dicta as to its exceptionality, ${ }^{114}$ an order's interlocutory nature seems a relatively minor factor in weeding out certiorari requests. The Court has not hesitated to grant certiorari when the question seemed sufficiently important. ${ }^{115}$ Even in the absence of a statutory policy, the Court has justified its consideration of an interlocutory ruling on the ground that its authoritative determination of the question was "fundamental to the further conduct of the case" below. ${ }^{110}$ Since 1292(b) expresses a congressional policy favoring those interlocutory appeals which are in much the same sense "fundamental to the further conduct of the case," the interlocutory character of the order should not detract from its eligibility for certiorari.

Denial of certiorari to review a 1292(b) decision on the merits would not bind the Supreme Court to the lower court's determination of the "law of the case"; it would still be free to consider the merits of the interlocutory order after final judgment.117 But as the court of appeals ordinarily would be bound by its own earlier ruling, ${ }^{118}$ it seems futile to require a second intermediate appeal as a prerequisite to certiorari. To avoid this step, when no other issue remains in the case, the parties could be allowed by the court of appeals to stipulate for immediate affirmance, or the Supreme Court could entertain the certiorari petition as soon as the appeal has been docketed. 110

Section 1292(b) contains two procedural requirements designed to prevent its use as a delaying tactic. First, application for permission to appeal must be made to the court of appeals within ten days from the entry of the order. The Third Circuit has construed this provision to mean that a district judge who initially neglects or refuses to certify an order cannot later do so after the ten-day period has lapsed. ${ }^{120}$ Even if other circuits follow this interpreta-

114. E.g., Larson v. Domestic \& Foreign Commerce Corp., 337 U.S. 682, 685 n.3 (1949) ; Land v. Dollar, 330 U.S. 731, 734 (1947). See Robertsos \& KIRrzass, op. cit. supra note 111, \& 130; Stern \& Gressman, Supreare Court Peactice 130 (2d ed. 1954).

115. See Myers v. Bethiehem Shipbuilding Corp., 303 U.S. 41, 52 (1938); Deckert v. Independence Shares Corp., 311 U.S. 282 (1940).

116. Larson v. Domestic \& Foreign Commerce Corp., 337 U.S. 682, 685 n.3 (1949); accord, United States v. General Miotors Corp., 323 U.S. 373, 377 n.2 (1945).

117. See 6 Moore, Fed. Practice If 54.08[2], at 56 (collecting 1292(a) cases).

118. See Smith v. Vulcan Iron Works, 165 U.S. 518, 525-26 (1897); 6 Afoore, Fen. Practice If 54.08[2], at 56.

119. See 28 U.S.C. \& 1254(a) (1958).

In New York, whenever a judgment of the Supreme Court is based on an Appellate Division decision made on previous interlocutory appeals, there can be direct appeal to the Court of Appeals, limited to the interlocutory order. See Underhill v. Schenck, 238 N.Y. 7, 143 N.E. 773 (1924). Alternatively, reappeal can be taken to the Appellate Division limited to the consideration of proceedings subsequent to the interlocutory order. Gambold v. MacLean, 254 N.Y. 357, 173 N.E. 220 (1930). If the latter course is chosen, appeal of all issues may be taken to the Court of Appeals. Logan v. Guggenheim, 230 N.Y. 19, 128 N.E. 903 (1920).

120. Milbert v. Bison Labs., Inc, 260 F.2d 431 (3d Cir. 1958). The circuit further ruled that if certification is added by amendment of the order, an appeal application must still be made within ten days of the original ruling; if, however, a party moves to amend the order, the time period begins again when the court disposes of the motion. Id. at 435-36. 
tion, a district judge may be able to avoid its effect by completely withdrawing his old order and issuing a new one including certification. ${ }^{121}$ The second, and more flexible and important, safeguard against delay is section 1292(b)'s proviso that trial court proceedings shall not be stayed during the interlocutory appeal, unless a district or circuit judge expressly orders to the contrary. ${ }^{122}$ While the statutory language can be read as withholding a stay only until the application for appeal is passed on, ${ }^{23}$ the legislative history makes clear that stay is to be withheld during all or any part of the appellate process. ${ }^{124}$ Issuance of a stay seems primarily a question for the district judge's discretion, and should be unnecessary when proceedings can be profitably conducted on two levels simultaneously. Thus if certification comes early in the proceedings, the appeal could often be decided before the case reaches trial; a stay therefore should be denied unless the remaining pretrial proceedings would be burdensome. This makes 1292(b) an unpromising weapon for delay. On the other hand, when trial or complicated, time consuming pretrial proceedings would occur before the appellate decision is expected, a stay is necessary fully to achieve the statute's purpose. "[I]f it be denied and the order is later reversed, the time and effort expended ... will have been wasted."125 Perhaps the most workable solution would be a conditional stay during the pendency of the appeal which becomes effective only in the event of trial or particular pretrial proceedings, such as an unusually difficult discovery, specified by the trial court.

Several problems apparently unanticipated by the draftsmen must be resolved by judicial ingenuity. Delay might still result from the statute's failure to specify a period for perfecting an appeal once an application to permit it has been granted. ${ }^{126} \mathrm{~A}$ solution is a strict time limit imposed either by rule of the court of appeals ${ }^{127}$ or by a specific condition in the district court's certification. ${ }^{128}$ Another danger of delay inheres in a losing party's power to defer his appeal from a certified order until after final judgment. ${ }^{120}$ Section $1292(b)$ is concerned with the time and expense of all litigants; a successful party on

121. "If it [an order] be only interlocutory, the court at any time before final decree may modify or rescind it." Simmons Co. v. Grier Bros. Co., 258 U.S. 82, 88 (1922); sce Ex parte Watkins, 260 F.2d 548 (5th Cir. 1958).

122. Accord, Der. Sup. CT. R. 22.

Stays during appeals under 28 U.S.C. $\$ \$ 1292$ (a) (1), (2), (4) are governed by FED. R. Crv. P. 62.

123. “. . application for an appeal hereunder shall not stay proceedings. ..." 28 U.S.C. § $1292(\mathrm{~b})$ (1958).

124. Hearings 11 (testimony of Judge Parker).

125. Bernhardt v.-Polygraphic Co. of America, 235 F.2d 209, 211 (2d Cir.), rcv'd, 350 U.S. 198 (1956).

126. See Oskoian v. Canuel, 264 F.2d 591, 594 (1st Cir. 1959).

127. E.g., 3D CIR. R. 11, as amended, December 2, 1958; 4TH CIR. R. 35.

128. See Oskoian v. Canuel, 264 F.2d 591, 594 (1st Cir. 1959).

129. Under 28 U.S.C. $\S 1292$ (a) (1958) a party may wait and raise the interlocutory order on appeal from final judgment without waiving his right to contest. See 6 Moone, Fed. Practice If 54.08-.09: Since there is no legislative expression of intent against the practice for $\S 1292(\mathrm{~b})$, the same rule will probably apply. 
such interlocutory orders as determinations of burden of prcof, and refusals to dismiss or transfer for improper venue would also have to go through an entire new trial if the order proves erroneous and results in reversal on final appeal. Since 1292(b) has no provision for certification on the judye's own motion, a solution is to permit the winning party to apply for, give notice of, and docket what is technically his opponent's appeal. ${ }^{130}$

More difficult is the problem of parties who attempt appeals by right of interlocutory orders, certifiable under 1292 (b), which they mistakenly bulieve to be "collateral" and therefore within section 1291's final judgment rule, or interlocutory orders appealable under 1292(a). In this situation, since the ten-day time limitation for application under the new section undoubtedly will have run before the appellate court denies the attempted appeal by right, an interlocutory appeal which would achieve the goals of 1292(b) will apparently be forfeited. On the other hand, it would do no violence to the section: language for a district judge, when an appeal by right is likely to be attempted, to make, in effect, a certification subject to the condition subsequent of an appellate finding that an appeal lies under 1291 or $1292(a)$. In this manner, the question would go up as a discretionary 1292(b) appeal, but if an appeal properly lies by right, the appellate court need not further expedite it. ${ }^{131}$ In order to avoid the danger of flooding the 1292 (b) calendar with all appeals other than those stemming from a traditional final judgment, a district judge who adopts the suggestion should grant conditional certification only when the same "substantial ground for difference of opinion" exists as to appealability by right as to the certified question itself.

\section{Analysis of 1292(b): Particular Orders}

For the purpose of the following analyses, it is assumed, unless otluervise specified, that a "substantial ground for difference of opinion" as to the correctness of the order exists, and that the court of appeals will agree to hear properly certified questions. These assumptions seem mandatory in view ui the unlikelihood of successful prediction in the abstract; they do not, however, detract from those factors' importance in actual cases. While the "controlling question" and "materially advance" criteria similarly will occasionally depend upon the framework of a particular litigation, their satisfaction may lie generally predicated according to the type of order in question.

130. This would be consistent with the statutory language, which requires only that "application is made" without specifying by whom. And an analogy is provided by rules which permit an appellee to perfect the appeal and have it stand for argument when the appellant has failed to do so. The appellee may also have the appeal dismissed. 20 CIR $R$. 14 (c) ; 3D CIR. R. 21 (4) ; see 1st CIR. R. 21 (3) (appellee may move that the case be docketed and dismissed; no provision for appellee perfecting the appeal).

131. Several circuits have made provision for expediting 1292 (b) appeals. Sce Communications From Judges of the Third, Fifth, Eighth and Ninth Circuits to the Yale Law Journal, April-June, 1959, on file in Yale Law Library. 


\section{Orders Concerning the Propriety of the Formm}

Refusals to dismiss for want of jurisdiction were clearly intencled to be appealable under 1292(b). A specific congressional example concerned appeal of an order denying dismissal for want of subject-matter juriscliction. ${ }^{13:}$ Similarly included would be refusals to dismiss for lack of proper venue, jurisdiction over the person, or failure to join an inclispensable party over whom personal jurisdiction cannot be obtained. Such questions are "controlling"; they go to the right to maintain the action. All four are therefore appealable under 1292(b) provided that they are made early enough for reversal to save a significant amount of trial time. If these defenses are asserted, as all may be, by motion under rule 12 (b), the "materially advance" requirement would be met; such motions must be made within twenty days after the complaint, ${ }^{1: a}$ and could ordinarily be disposed of promptly. If raised by answer or reply to a counterclaim, these questions likewise would appear before trial, or active preparation therefor. ${ }^{134}$ Only the subject-matter and indispensable-party ob. jections may be delayed beyond the answer, ${ }^{135}$ in which case they will often fail to meet the "materially advance" requirement. Another situation in which denying a claim of no jurisdiction would not materially advance the litigation occurs in a multiclaim suit when federal jurisdiction over one claim is undisputed. Refusal to dismiss a second cause of action involving the same parties and similar facts would neither prolong the proceedings nor entail the risk of their being rendered nugatory on final appeal.

An additional species of orders concerning which court shall hear a case, to which 1292 (b) is applicable, are those granting or denying motions for change of venue. ${ }^{136}$ When an order transferring, or refusing to transfer, venue is challenged on the ground that the forum selected lacks juriscliction, ${ }^{137}$ the

132. S. REP. 2; see Rogers v. Schilling, No. 14723, D.C. Cir., May 21, 1959 (notion to dismiss for lack of jurisdiction denied and certified by district court; Court of Appeals reversed on grounds that suit attempted to gain judicial determination of question committed by Congress to administrative agency); Cordero v. Panama Canal Co., $170 \mathrm{~F}$. Supp. 234 (S.D.N.Y. 1959) (certification granted on denial of motion to dismiss for lack of jurisdiction under Jones Act) ; Bobolakis v. Compania Panamena Maritima San Gerassimo, S.A., 168 F. Supp. 236 (S.D.N.Y. 1958) (certification denied on refusal to dismiss for want of Jones Act jurisdiction, even though there was doubt on the correctness of the order, because no material advance shown).

133. See FED. R. Crv. P. 12(a).

134. Ibid.

135. FED. R. CIv. P. 12(h).

136. Transfer of venue generally is provided for in 28 U.S.C. $\S \S 1404$ (a), 1406(a) (1958).

Previously, decisions on venue transfer could be reviewed only by extraordinary writ or on final appeal. See Chas. Pfizer \& Co. v. Olin Mathieson Chem. Corp., 225 F.2d 718 (5th Cir. 1955) (transfer of venue not appealable as "collateral" order).

137. Section 1292(b) has been used in two cases in which a transfer under $\S 1404$ (a) was granted but the transferee court was alleged to lack jurisdiction. Continental Grain Co v. Federal Barge Lines, Inc., 268 F.2d 240 (5th Cir. 1959); Orzulak v. Federal Com- 
question raised is "controlling" since reversible error could result.13s . In!l immediate appeal "may materially advance the ultimate termination of the litigation" by saving an entire trial. When the challenge to venue rests instead on forum non conveniens grounds, the question may still be "controlling" because of the increased expense of an inconvenient forum. ${ }^{130}$ Thile reversal of such a venue order would significantly shorten the litigation if dockets were considerably less crowded in the alternative venue (provided the appeal itseli would not be inordinately long), ordinarily time so saved would have been spent inactively awaiting trial. Therefore, although appeal would "advance the ultimate termination of the litigation," it would not "materially" do so, unless plaintiff demonstrated an exceptional need for prompt compensation. ${ }^{1 * 0}$ On the other hand, if reversal of such an order would, in the trial judge's opinion, induce settlement, the "materially advance" requirement would be met. Of course, since "substantial grounds for difference of opinion" will seldom exist on a discretionary issue such as forum non conveniens, 1292(b) appeals of these orders will be rare. ${ }^{141}$

Section 1292 (b) seems especially useful in affording immediate review of decisions denying remand of actions removed from state courts. ${ }^{1.2}$ Heretofore, such orders were appealable only after final judgment, ${ }^{143}$ when reversal would nullify an entire federal trial, and leave the parties to begin again in a state court. ${ }^{144}$ Thus, an interlocutory appeal would satisfy both the "controlling question" and "materially advance" tests. Section 1292(b) seems inapplicable to orders granting remand, ${ }^{145}$ since prior legislation, which $1292(\mathrm{~b})$ has

merce \& Nav. Co., $168 \mathrm{~F}$. Supp. 15 (E.D. $\mathrm{Pa}$. 1958). The issue could also arise when the court overrules a $\$ 1405$ (a) motion for transfer premised on the existing forum being improper, but this would in effect be a denial of a motion to dismiss for lack of venue.

138. See, e.g., Gulf Research \& Dev. Co. v. Leahy, 193 F.2d 302 (3d Cir. 1951).

139. See Note, 67 YaLE L.J. 122, 124 (1957).

140. See text at notes 90-91 supra.

141. See Deepwater Exploration Co. v. Andrew Weir Ins. Co., 167 F. Sugp. 185 (E.D. La. 1958) (Congress did not intend that $\S 1292$ (b) would be used to reviev discretion of district judge in granting or denying transfer of venue on forum non conveniens grounds).

142. Remand is governed by 28 U.S.C. $\$ 1447$ (c) (1958).

143. Wynn v. RFC, 212 F.2d 953 (9th Cir. 1954); Tinkoff v. Holly, 209 1:.2d 527 (7th Cir. 1954) ; Lewis v. E. I. du Pont de Nemours \& Co., 183 F.2d 29 (5th Cir. 1950). Interlocutory review could be obtained under 28 U.S.C. \& 1292(a) (1) (1958) when the denial was accompanied by an injunction against further proceedings in state court. Albi v. Street \& Smith Publications, 140 F.2d 310 (9th Cir. 1944); Johnson v. Butler Bros., 162 F.2d 87 (8th Cir. 1947):

144. Review by mandamus has rarely succeeded. Compare $E x$ parle Park Square Auto. Station, 244 U.S. 412 (1917) (denying mandamus); Ex fartc Roe, 234 U.S. 70 (1914) (same); Ex parte Nebraska, 209 U.S. 436 (1908) (same), asd In re Pollitz, 206 U.S. 323 (1907) (same), with Ex parte Wisner, 203 U.S. 449 (1906) (granting mandamus), and In re Winn, 213 U.S. 458 (1909) (same).

145. In re Bear River Drainage Dist., 267 F.2d 849 (10th Cir. 1959). 
apparently left untouched, prohibited review of such orders, either by appeal or prerogative writ. ${ }^{146}$

\section{Orders Staying the Action}

Interlocutory appeal of orders granting or denying a motion for a stay of proceedings depends, apart from 1292 (b), on whether the action is one at law. If so, the grant of a stay is characterized as an injunction by an equity court of a legal action, and a refusal as a refusal to enjoin. Thus, both would be appealable under 1292 (a) (1). ${ }^{147}$ Section 1292 (b) does not affect such stays since they are "otherwise appealable," but it can extend interlocutory review to orders granting or denying a stay in equity suits. Grants or refusals of stays pending arbitration raise a "controlling question of law" because, if erroneous, they constitute reversible error. ${ }^{148}$ Moreover, appeal of such grants "may materially advance" the litigation, provided the arbitration, to which the parties would have to turn, would be prolonged enough to be significant. Appeal of such refusals would also meet this requirement, since an entire trial could be saved. Grants of stays pending the outcome of a second suit decisive of the case at bar, while probably "controlling," because possibly determinative of the outcome, will probably not satisfy the "materially advance" requirement. But an improper refusal will be "controlling" when it causes the parties to engage in an expensive and difficult litigation, and an appeal "may materially advance" the case whenever the time and effort necessary for completion of the second suit are significant compared to that of an appeal.

\section{Orders Determining Parties}

Section 1292 (b) may cover a wide variety of orders determining who will participate in a lawsuit. A specific example in the legislative history indicates that the section covers orders permitting or denying impleader whenever "the presence of the third-party defendant is the only reason for going on with the

146. See 28 U.S.C. § 1447 (d) (1958); Lewis v. United Gas Pipe Line Co., 194 F.2d 1005 (5th Cir. 1952); Collier v. Lederle, 252 F.2d 804 (6th Cir. 1958).

Should it be held that $\S 1447$ (d) is repealed pro tanto by $\S 1292$ (b), however, the latter section would rarely be satisfied. Only when a material difference in outcome would result from a change in forums would the question be "controlling." And the "materially advance" requirement could be surmounted only if the words "the litigation" are read to encompass proceedings outside the federal system, since the litigation is terminated so far as the federal courts are immediately concerned.

147. Ettelson v. Metropolitan Life Ins. Co., 317 U.S. 188 (1942); Enelow v. New York Life Ins. Co., 293 U.S. 379 (1935); Shanferoke Coal \& Supply Corp. v. Westchester Serv. Corp., 293 U.S. 449 (1935). Thus when the original suit is equitable in nature, the stay is unappealable since a court of equity could not have enjoined itself. See Baltimore Contractors, Inc. v. Bodinger, 348 U.S. 176 (1955); City of Morgantown v. Royal Ins. Co., 337 U.S. 254 (1949).

148. Bernhardt v. Polygraphic Co. of America, 235 F.2d 209 (2d Cir.), rev'd, 350 U.S. 198 (1956). 
suit"149-whenever an appellate denial of impleader would cause settlement. When the trial judge diagnoses such a situation, he should allow appeal, since, under rule 14, motions for third-party practice must be raised early in the proceedings. If the primary suit will continue regardless of the fate of the thirdparty complaint, the question may be "controlling" in two situations-when a third-party defendant's improper presence in an action will substantially increase the expense and difficulty of the action, and when his improper absence will force the plaintiff to prosecute two suits in order to obtain full compensation. While appeal of an erroneous grant of an impleader motion would end the litigation for the impleaded party, the litigation as a whole would not be materially advanced, except in the exceptional case where the unwarranted presence of a third party substantially delay's the primary suit. On the other hand, appeal of an incorrect denial of an impleader motion may save an entire subsequent trial between defendant and third-party defendant, and would be proper if undue delay to plaintiff's suit would not result.

Like impleader, any motion concerning joinder presents a "controlling question" as far as the joined party is concerned because it deternines his right to participate in the litigation. In addition, when joinder is necessary 150 rather than permissive, ${ }^{151}$ the question is "controlling" since it determines whether the original parties will get complete relief. The requirement that immediate appeal may materially advance the case will be satisfied when the challenged order would warrant reversal of the entire suit on final appeal; thus the court's failure to join a party allegedly indispensable under rule 19 should be appealable under 1292(b). And since, by the terms of rule 19, complete relief cannot be afforded the original litigants unless a "necessary" party is in the suit, ${ }^{152}$ prompt reversal of an erroneous failure to join such a party could also "materially advance the ultimate termination of the litigation." Denying a motion to drop a party for misjoinder under rule 21 , or granting a motion for joinder under rule 19, should not ordinarily be immediately appealable, since they could constitute reversible error only as to the party erroneousl: retained in the suit. ${ }^{153}$ Section 1292(b) should not be satisfied by advancing "the ultimate termination of the litigation" only for him. Similarly, immediate reversal of an erroneous refusal of permissive joinder might also save the parties an extra suit. But the "substantial ground for difference of opinion" test would not ordinarily be met.

Rule 24 permits anyone to intervene in an action either by right or by permission of the court. The courts have long recognized the fundamental nature of a claim of right to intervene and have allowed a denial to be appealed as

149. Hearings 9 (testimony of Judge Parker); see Lohr v. United States, 264 F.2d 619 (5th Cir. 1959), cert. denied, 80 Sup. Ct. 51 (1959).

150. See FEd. R. Crv. P. 19.

151. See FED. R. CIV. P. 20.

152. See Moore, Federal Rules and Offictal Forars 131 (1956).

153. See Finn v. American Fire \& Cas. Co., 207 F.2d 113 (5th Cir. 1953), ccrs. deried, 347 U.S. 912 (1954); cf. Meyercheck v. Givens, 180 F.2d 221 (7th Cir. 1950). 
"final."154 Orders granting either type of intervention would meet the "controlling question" and "materially advance" requirements for all parties only when the intervenor's presence in the suit would reshape the litigation so as substantially to complicate and lengthen it for the original litigants. Refusal of permissive intervention under rule 24 (b) (1) (statutory right of conditional intervention) or 24 (b) (2) (common question of law or fact) would scem appealable under 1292(b) under the same conditions as a denial of impleader motions, ${ }^{155}$ except that the discretionary nature of permissive intervention makes any "substantial ground for difference of opinion" unlikely.

An order granting or denying substitution ${ }^{160}$ for one party in a two-party suit is clearly "controlling," since any error would be reversible on final appeal. When improper substitution is permitted, the "may materially advance" criterion is met, since immediate reversal would prevent a wasted trial. Denying substitution, when it is clear that someone else will be allowed to substitute, should be appealable for much the same reasons. On the other hand, when substitution is refused everyone, an immediate appeal would not "materially" advance" the outcome. Dismissal will soon follow and could be appealed as a final judgment. Similarly, in a two-party suit, the question of a party's capacity to sue or be sued is "controlling," since it goes to the right to maintain an action. It must be raised in the pleadings or earlier, ${ }^{157}$ so that prompt appellate determination could "forestall what might well be a long and expensive trial."158

\section{Orders Concerning Dismissal and Judgment}

Appeal of a denial of a 12(b) (6) motion that a complaint fails to state a claim upon which relief can be granted will meet the "controlling question" and "materially advance" standards only in the unusual case in which the asserted pleading defect could not readily be cured by amendment. ${ }^{150}$ Otherwise, appeal could prolong the proceedings. Sometimes, however, when reversal would establish that plaintiff's case was essentially faulty, rather than

154. See, e.g., Brotherhood of R.R. Trainmen v. Baltimore \& O.R.R., 331 U.S. 519 (1947).

155. See text following note 147 supra.

156. If a party dies and the claim is not thereby extinguished, the court within two years after the death may order substitution of parties. If substitution is not so made, the action shall be dismissed as to the deceased party. FED. R. CIV. P. 25(a); see In re Sylvania Elec. Prods., Inc., 220 F.2d 423 (1st Cir. 1955).

157. See Fed. R. Crv. P. 7 (b), 9(a); Coburn v. Coleman, 75 F. Supp. 107 (W.D.S.C. 1947).

158. Oskoian v. Canuel, 264 F.2d 591, 594 (1st Cir. 1959).

159. Most pleading errors can be remedied under the liberal amendment provisions of FED. R. CTv. P. 15(b), and therefore would not be appealable. Gottesman v. General Motors Corp., 268 F.2d 194 (2d Cir. 1959) ; Kroch v. Texas Co., 167 F. Stupp. 947 (S.D.N.Y. 1958); of. Sperry Rand Corp. v. Bell Tel. Labs., Inc., 173 F. Supp. 714 (S.D.N.Y. 1959) (certification of order denying leave to amend as attempt to insert new issues). But cf. Biggers v. Bankers Bond Co., 171 F. Supp. 94 (W.D. Ky. 1959) (certi. fication denied of order refusing permission to amend counterclaim). 
badly pleaded, ${ }^{100}$ such as appeal of a denial of a $12(\mathrm{~b})(6)$ motion raising an affirmative defense, in the nature of a plea in bar, ${ }^{101}$ appeal would be proper. For example, Austrian $v$. Willians, ${ }^{102}$ a case frequently cited in the House hearings as suited to 1292 (b) appeal, ${ }^{103}$ involved an erroneously denied 12(b) (6) assertion of a statute-of-limitations defense. Considerations similar to those involved in appeals of 12 (b) (6) rulings are presented by motions for judgment on the pleadings under rule $12(\mathrm{c})^{164}$ and motions to strike under rule 12 (b).

Orders denying summary judgment under rule $56,{ }^{165}$ when the decision is challenged as an erroneous interpretation of law, would usually meet the standards of 1292 (b) ${ }^{160}$ But when the reason for denying a summary judgment motion (or a 12 (b) (6) or 12 (c) motion which goes outside the pleadings and therefore is deemed a rule 56 motion) is the trial court's belief that a material factual dispute exists, 1292 (b) would rarely be satisfied. A "controlling question of law" might be involved, on the theory that erroneous denial of the motion would be prejudicial error if the moving party loses on final judgment; the "materially advance" criterion would be satisfied, since appeal would render trial unnecessary. But the unlikelihood of reversal on a point so peculiarly within the trial court's ken makes it improbable that the "substantial difference of opinion" test could be met. When summary judgment is granted on all claims in dispute, it is of course appealable like any final judgment, ${ }^{10 t}$ and when granted on less than all claims its certification for appeal is governed by rule 54 (b).$^{168}$ If trial of damages would be extensive, legislative history is clear that, in line with patent and admiralty practice, ${ }^{100}$ resort to 1292 (b) would also be appropriate when the court renders "summary judgment, interlocutory in character . . . on the issue of liability alone . . . ."170

\section{Provisional Remedies}

Section 1292(b) is inapplicable to the provisional measures of injunction under rule 65 or receivership under rule 66 , since their grant or denial is "other-

160. E.g., Feinberg v. Leach, 243 F.2d 64 (5th Cir. 1957).

161. For the affirmative defenses which may be raised under FEn. R. Crv. P. 12(b)6, See 2 MOORE, Fed. Practice III 12.09-.10.

162. 198 F.2d 697 (2d Cir. 1955).

163. Hearings $8,13,23,24$.

164. See Sinclair Ref. Co. v. Stevens, 123 F.2d 186 (8th Cir. 1941) (motion successiul).

165. Such an order is not appealable as final. See Dutton v. Cities Serv: Defense Corp., 197 F.2d 458 (8th Cir. 1952). But see Federal Glass Co. v. Loshin, 217 F.2d 936 (2d Cir. 1954), allowing interlocutory appeal of an order denying summary judgment in an injunctive suit, as the denial of a preliminary injunction.

166. See Bertha Bldg. Corp. v. National Theatres Corp., 269 F.2d 785 (2d Cir. 1959) (refusal to grant motion for summary judgment based on statute of limitations certified and affirmed by court of appeals).

167. See, e.g., Lamb v. Shasta Oil Co., 149 F.2d 729 (5th Cir. 1945).

168. Wynn v. RFC, 212 F.2d 953 (9th Cir. 1954).

169. See FED. R. Crv. P. 56(c). Such an order is not final for purposes of appral. Canister Co. v. National Can Corp., 163 F.2d 683 (3d Cir. 1947) ; 6 Mfoone, Fed. Practice If 56.20 [4], at 2312 .

170. FED. R. Crv. P. 56(c); see Hearings 8. 
wise appealable" under 1292 (a). Nor does it apply to orders withholding other provisional relief, such as attachment, under rule 64 , which incorporates state procedure, since those are appealable as "final" under the collateral-order doctrine. ${ }^{171} \mathrm{~A}$ grant of, or a refusal to vacate, rule 64 remedies is, however, an interlocutory decision, ${ }^{172}$ but 1292 (b)'s requirements will be difficult to meet. The question of law is not ordinarily "controlling" just because of the hardship resulting from the remedy; this probably would not be considered a cost of litigation. And although the question could be "controlling" when the practical effect of the remedy is to induce settlement by defendant, appeal would always prolong rather than advance the litigation.

\section{Orders on Discovery and Its Enforcement}

Orders allowing or denying discovery or production of documents during litigation are not appealable under 1291 or $1292\left(\right.$ a) $; \boldsymbol{;}^{173}$ unless prepared to suffer entry of adverse judgment as a sanction for noncompliance with the order, a party ordinarily cannot obtain review until after judgment on the merits. ${ }^{17.1}$ By then no issue may remain, or reversal may be refused because the crror cannot be shown to have been determinative of the outcome. ${ }^{175}$ Even the grant of a new trial could not eliminate the effect of information improperly discovered ${ }^{176}$ or reimburse the expense occasioned by discovery erroneously forced upon a party, or by costlier alternative means of gaining information when discovery was wrongly withheld. As a result legislation has been suggested to provide discretionary review for discovery orders. ${ }^{177}$ Section 1292 (b) might be utilized to achieve such review. The practical impact of discovery may make many of these orders "controlling," while those which may constitut: reversible error are "controlling" on that count. The requirement for "materially advancing the ultimate termination of the litigation" would be met when prompt appellate action would foreclose the danger of reversible error

171. E.g., Swift \& Co. Packers v. Compania Colombiana Del. Caribe, S.A., 339 U.S. 684 (1950); see 7 Moore, Fed. Practice II 64.10.

172. See Cushing v. Laird, 107 U.S. 69 (1883) ; Flegenheimer v. General Mills, Inc., 191 F.2d 237 (2d Cir. 1951).

173. See Alexander v. United States, 201 U.S. 117 (1906) ; Carolina Power \& Light Co. v. Jernigan, 222 F.2d 951 (4th Cir. 1955); Dille v. Carter Oil Co., 174 F.2d 318 (10th Cir.), cert. denied, 338 U.S. 850 (1949).

174. See 4 Moore, Fed. Practice $\llbracket 26.37$ [7], at 1219. But see Overby v. United States Fid. \& Guar. Co., 224 F.2d 158 (5th Cir. 1955) (order for production of government documents in the bank's control over claim of privilege by the government held final and appealable because U.S. not a party and once produced, its claim is worthless); Bank of America Nat'l Trust \& Sav. Ass'n v. Douglas, 105 F.2d 100 (D.C. Cir. 1939) (appealable injunction used to prevent burdensome discovery when not a party to the action); cf. Mosseller v. United States, 158 F.2d 380 (2d Cir. 1946) (ruling on petition for a deposition to perpetuate testimony for use in a future action is final and appealable).

175. See 4 MOore Fed. Practice $\int$ 26.37[6], at 1218-19.

176. 4 id. at 1219 .

177. 4 id. $\llbracket 26.37[7]$, at 1221 . 
requiring a new trial, or would cause a party to drop or settle the suit, ${ }^{178}$ or would save prolonged preparations. While these requirements would not be met by discovery orders in simple suits, such as ordinary accident cases, appeal will nonetheless be available in cases smaller than the mammoth antitrust litigation. And even when the grant of discovery does not meet these requirements, enforcement by prohibiting contest on part of the merits under rule 37(b) (ii) - which probably can be reversible error-would qualify for a 1292(b) appeal ${ }^{179}$ which would encompass the correctness of the original grant of discovery. 180 In the event of interlocutory affirmance, the party could still comply with the discovery order, and contest the merits, whereas a $37(b)$ order for default judgment, if resisted on final appeal and upheld, would determine the lawsuit against him. Interlocutory review of these enforcement orders should not encourage dilatory or frivolous appeals, since the appellate courts' attitude of affirming any reasonable exercise of the trial judge's discretion concerning discovery ${ }^{181}$ should usually deter him from certifying that a "substantial difference of opinion" exists.

\section{Orders Concerning Jury Trial}

Orders delaying, or refusing to delay, jury trial pending the adjudication of an equitable claim are appealable as of right, since under Enclon' ' $\mathrm{Nca}^{*}$ York Life Ins. Co. ${ }^{182}$ they are categorized as orders granting or denying an injunction. But no interlocutory appeal lies as of right from other orders implementing or rejecting a demand for a jury. ${ }^{183}$ This arbitrary definition of the scope of review has been criticized, ${ }^{184}$ and the alternative of mandamus usually fails. ${ }^{185}$ Section 1292 (b) does not eliminate the problem of categorization, since it excepts orders "otherwise appealable" as injunctions, but it can alleviate the effect of the distinction by making appeal also available for non-

178. He might prefer this to submitting to discovery sufficiently burdensome to negate any advantage expected from continuing the litigation, or disclosing material he is ansious to keep secret.

179. The possibility of shortening the trial or preventing reversible error might also make orders holding a party in contempt appealable.

180. Interlocutory appeal once granted brings up all orders which while basic to the appealable order are not themselves appealable. MOORE, Cossarentary 0:: trie C:irten States Judicial Code If 0.03 [52], at 488, 489 (1949).

181. See, e.g., Bank of America Nat'l Trust \& Sav. Ass'n v. Hayden, 231 F.2d 595, 606 (9th Cir. 1956).

182. 293 U.S. 379 (1935); accord, Ettelson v. Mfetropolitan Life Ins. Co., 317 U.S. 188 (1942).

183. E.g., City of Morgantown v. Royal Ins. Co., 337 U.S. 254 (1949).

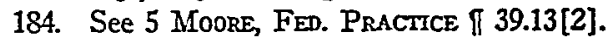

185. See, e.g., Institutional Drug Distribs., Inc. v. Yankwich, 249 F.2d 566 (9th Cir. 1957); In re Previn, 204 F.2d 417 (1st Cir. 1953); Petsel v. Riley, 192 F.2d 954 (8th Cir. 1951); In re Pan-American Life Ins. Co., 188 F.2d 833 (5th Cir. 1951); Ex parte Mason, 244 Fed. 154 (8th Cir. 1917). But see Ex parte Skinner \& Eddy Corp., 265 U.S. 86 (1924); Black v. Boyd, 248 F.2d 156 (6th Cir. 1957); Bereslavshy v. Caffey, 161 F.2d 499 (2d Cir. 1947). 
injunctive jury-trial orders. These can be "controlling" because, if erroneous, they entitle the aggrieved party to reversal. 180 Provided the lower court determines the issue early enough in the proceedings, the "materially advance" criterion will be satisfied as well.

\section{Orders Relating to Masters}

Reference of issues to a master, permitted by rule 53(b) in "exceptional cases," has on occasion been reversed by mandamus. ${ }^{187}$ Section 1292 (b) certification may also be available. The order of reference may be "controlling" because such an outcome-determinative change in the trier-of-fact might entail reversible error, ${ }^{188}$ and because the additional burden on the parties may have a serious impact on the conduct of, and net recovery from, the suit. ${ }^{180}$ The delay that may result from reference ${ }^{100}$ can satisfy the "may materially aclvance" standard. But reference and refusal to do so do not seem to be the type of orders in which a "substantial ground for difference of opinion" will frequently exist. ${ }^{191}$ Moreover, the likelihood of immediate appeal of refusal to make a reference materially advancing the litigation is slight. Once the master's report is submitted and decisions, which are potentially reversible error, rendered on the objections thereto, their appealability under 1292(b) should depend on the prospective length of proceedings remaining.

\section{Orders at Trial}

Points arising during the trial ${ }^{102}$ should rarely qualify for 1292 (b) review. Although some afford grounds for reversal, and so can be termed "controlling,"

186. City of Morgantown v. Royal Ins. Co., 337 U.S. 254, 258, 263-64 (1949).

187. See LaBuy v. Howes Leather Co., 352 U.S. 249 (1957).

188. While no decision has been found reversing a final judgment because the case was erroneously referred to a master, the Supreme Court has hinted that reversal may be appropriate. See id. at 258; cf. Sutton v. Johnson Cotton Co., 114 F.2d 302 (4th Cir. 1940) (final judgment in action at law reversed when ordered by district judge on basis of master's report containing no findings of fact or conclusions, and without submission of report to jury or granting party opportunity to submit evidence to jury). If reversal does not take place the cost of the referral may be charged to the party who wrongly requested it. Adventures in Good Eating, Inc. v. Best Places To Eat, Inc., 131 F.2d 809 (7th Cir. 1942).

189. See Adventures in Good Eating, Inc. v. Best Places To Eat, Inc., supra note 188, at 814-15 ("references greatly increase the cost of litigation and delay and postpone the end of litigation.") ; LaBuy v. Howes Leather Co., 352 U.S. 247, 262 (1957) (dissenting opinion); Note, 65 YaLE L.J. 1057, 1060-62 (1956).

190. See Helfer v. Corona Prods., 127 F.2d 612 (8th Cir. 1942), a case in which a master was appointed and heard the evidence in 4 days, but died before making his report: on appointment of a second master, 19 months elapsed before he made his report.

191. See Barnard-Curtiss Co. v. Maehl, 117 F.2d 7 (9th Cir. 1941); Buckley v. Altheimer, 152 F.2d 502 (7th Cir. 1945).

192. E.g., questions on the admissibility of evidence, competency of witnesses, prejudicial statements to the jury, improper conduct by the judge, improper conduct of a juror, instructions to the jury, rulings on law such as burden of proof or conflict of laws. 
they ordinarily occur too close to final judgment for immediate appeal materially to advance the litigation. Another restriction on 1292(b)'s applicability to trial proceedings is its limitation to "orders."193 Decisions that are considered "rulings," as on admissibility of evidence, seem to fall outside the statute.

But an order granting a new trial is "controlling," because, if erroneous, it would require reversal of a different verdict found at a second trial. ${ }^{194}$ Since an appellate decision sustaining the original verdict would avert the need for a second proceeding below, 1292(b) should authorize appeal by the party seeking to retain the original verdict, and cross-appeal by his adversary who probably had moved in the alternative for a new trial or judgment n.o.v. Immediate appeal under 1292(b) will be particiularly helpful to a party faced with the dilemma of a new trial order conditioned on noncompliance with a remittitur. ${ }^{195}$ Certification of the new trial order could also resolve the anomaly whereby, when such order is granted in the alternative with judgment n.o.x., the appellate court can review only the latter, ${ }^{100}$ even if its examination of the record would enable it as easily to decide both.

\section{Conclusion}

Although several opinions have suggested that 1292(b) should be restricted to the "big" case. ${ }^{197}$ such a restriction seems both improper and unnecessary. The very terms of the statute, if carefully applied, are sufficient to prevent abuse; particularly useful in preventing appeals of insignificant cases is the "substantial ground for difference of opinion" test, which the previous discussion has usually presumed satisfied. Moreover, the system of discretionary appeals established by 1292 (b) cannot "be used for the purpose of postponement and delay" as easily as can a system of interlocutory appeals by right. ${ }^{109}$ Most applications for 1292(b) appeal in the first six months of the act were decided in less than a month, ${ }^{199}$ so that opportunity for delay would be slight even were a certification improvidently allowed. In sum, the intelligent use of section 1292(b) will beneficially affect federal practice by simplifying and expediting the process of litigation.

193. "When a district judge, in making in a civil action an order . . . "2\$ U.S.C. § 1292 (b) (1958).

194. See Standard Oil Co. v. Brown, 238 F.2d 54, 56 (5th Cir. 1956); Finn v. American Fire \& Cas. Co., 207 F.2d 113 (5th Cir. 1953); American Mfrs. Miut. Ins. Co. v. WilsonKeith \& Co., 247 F.2d 249 (8th Cir. 1957); Altrichter v. Shell Oil Co., 161 F. Supp. 46 (D. Minn. 1958).

195. See, e.g., Arkansas Valley Land \& Cattle Co. v. MIann, 130 U.S. 69 (1839); Butler v. General Motors Corp., 143 F. Supp. 461 (N.D.N.Y. 1956).

196. See Montgomery Ward \& Co. v. Duncan, 311 U.S. 243 (1940).

197. See cases cited note 69 supra.

198. See Hearings 9 (testimony of Judge Parker).

199. Director of the Administrative Office of United States Courts, 2d Quarterly Report, Feb. 15, 1959, p. 3. 